\title{
最近の歯学
}

\section{5. 口腔総合診断}

\section{睡眠呼吸障害に対する歯科的アプローチ}

東京医科歯科大学歯学部口腔総合診断学講座 瀧本賢一郎, 俣木志朗

近年, 睡眠呼吸に関連する疾患への関心が高まりつつある。 しかし我が国では, 診査・診断はもとより, 診療体制も十分 に整備がなされているとはいえず，欧米諸国に大きく遅れを とっているともいわれている。

睡眠時無呼吸症候群 (Sleep Apnea Syndrome: SAS) は, 呼吸器科, 循環器科, 耳鼻咽喉科, 小児科, 精神科, 歯科な どの多領域にまたがる疾患である。SAS は，7時間の睡眠中 に 10 秒以上の気流の停止が 30 回以上，または睡眠 1 時間当 たり 5 回以上 (Apnea Index：AI $\geqq 5$ ) 起こる状態を指すと されている。また，この $\mathrm{AI}$ が 20 以上になると， 5 年以後の 生存率が低下するとの報告もみられる。

SAS は, 無呼吸発作中に努力呼吸が認められる閉塞型 (Obstructive SAS : OSAS) と, 努力呼吸が認められない中 枢型 (Central SAS：CSAS) と, 同じ無呼吸発作中に両者が 混在する混合型に大別されるが, 閉塞型が大部分を占めてい る。なお，その有病率については, 各調査にばらつきがある ものの, 人口の約 $1 \%$ とされ, 我が国では 130 万人ぐらい潜 在しているのではないかとの推測もなされている。

OSAS での無呼吸発作は, 扁桃肥大, アデノイド，小顎症， 下顎骨後方偏位などの形態学的異常や, 上気道筋緊張の低下, 同コンプライアンスの増加などの機能的異常が, 上気道の狭 窄を引き起こすことによるものと考えられている。また，そ の臨床症状として, 習慣性の強い鼾や日中傾眠, 睡眠中の頻 回覚醒や異常体動などが挙げられているが, 自覚症状を伴わ ない場合も少なくないようである。

鑑別診断にあたっては問診や質問紙法に加えて, 終夜睡眠 ポリグラフ(Polysomnography), パルスオキシメーターによ る検査, セファロメトリー(頭部 X 線規格撮影) による上気 道形態の評価などが行われている。

OSASの治療法としては, かつては気管切開などが主流で あったが, 現在では, 外科的手術に加えて, 持続的陽圧呼吸 装置 (Continuous Positive Airway Pressure : CPAP) の応 用, 減量療法, 薬物療法などが試みられている。また歯科的 アプローチとして, 比較的軽度の OSASに対する口腔内装具 (スプリント)を用いた治療法が注目されはじめている。その 際, 支持力が十分に得られる残存歯が存在すること, 高度の 鼻閉や顎関節症のないこと, 明らかに手術適応と思われる解 剖学的異常のないことなどが条件として挙げられている。こ
の歯科的アプローチはいわゆる保存療法であり, 簡便性に優 れるといった利点を有するが，いまだその有効性は必ずしも 明らかにされていない。また, 顎関節に負担がかかる等の問 題点も指摘されている。

最近, 歯学部附属病院を訪れた歯科患者約 1,000 名に対し, アンケート調查を行って睡眠呼吸障害のスクリーニングを試 みたところ, 男女合わせて 39 名に何らかの睡眠呼吸障害が疑 われた。そこでパルスオキシメーターによる検査を行い, 無 呼吸や鼾によると思われる動脈血酸素飽和度の低下が顕著に みられた症例に口腔内装具(スプリント：図 1) を装着し，そ の効果を現在確認中である。

このように，睡眠呼吸障害は歯科領域にもきわめて密接な 疾患と考えられ, 今後, 関連する他科との連携を困りながら, 本疾患の病態の解明や治療法の確立を進める必要があろう。

\section{文献}

1）中川健三：本間日臣編, 睡眠時無呼吸症候群. 1996, 克 誠堂出版, 88-98.

2）榊原博樹：歯科装具による睡眠時無呼吸の治療とセファ ロメトリー。治療学 30：201-206, 1996.

3）柇原博樹：歯科装具・ その他の治療法. 日本胸疾誌 33 (別冊)：76-84， 1995.



図 1 無呼吸用スプリントの一例 